DOI 10.37882/2500-3682.2020.07.21

\title{
КУЛЬТУРНОЕ СТРОИТЕЛЬСТВО В СЕЛЬСКОЙ МЕСТНОСТИ РОССИИ ${ }^{1}$
}

\section{CULTURAL CONSTRUCTION IN RURAL AREAS OF RUSSIA ${ }^{2}$}

\section{Zhang Hongli He Qiang}

Summary: The process of globalization has led to approximately common problems faced by people living in rural areas in many countries of the world. The key problems include, first of all, the search for activities that can bring real, permanent income and at the same time generate employment.

In this regard, it should be noted that in Russia, the rural economy can be called a single-industry economy, since agriculture is still the main sphere of employment in rural areas. The situation is further complicated by the low level of labor productivity in the industry. Some experts say that it is 8-10 times lower than in the most developed countries. The low level of labor productivity is due to insufficient investment and technological factors, as well as the underdevelopment of other areas of employment of rural residents.

The development of rural tourism and active cultural construction in rural areas of Russia will be able to turn the situation around.

Keywords: cultural construction, rural area, cultural heritage, houses of culture, historical memory.

\section{Введение}

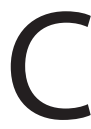

ело - исторически сложившаяся, специфическая, социально-территориальная ,поселенческая общность, возникшая вследствие отделения ремесла от земледелия, одна из первых форм расселения людей, занятых преимущественно сельскохозяйственным трудом, отличающаяся от города малой концентрацией и небольшой численностью населения в пределах определенной территории. [6]

Особенностями села являются, во-первых, сниженная по сравнению с городом комфортность быта, во-вторых, неравномерность трудовой занятости, связанная с цикличностью сельскохозяйственных работ и необходимостью учитывать погодно-климатические условия, в-третьих, необходимость ведения приусадеб-

\author{
Чжан Хунли \\ Профессор, Цичикарский университет, КНР, Цичикар \\ zhanghongli8335@126.com \\ Хэ Цян \\ Профессор, Цицикарский университет, КНР, Цицикар \\ heqiang1969@163.com
}

Аннотация: Процесс глобализации привел к примерно общим проблемам, с которыми сталкиваются жители сельских поселений во многих странах мира. К ключевым проблемам следует отнести в первую очередь поиск той деятельности, которая сможет приносить реальный, постоянный доход и одновременно формировать занятость.

В этой связи, следует обратить внимание, что в России сельскую экономику можно назвать моноотраслевой, так как по-прежнему сельское хозяйство является основной сферой приложения труда на селе. Ситуация ещё больше осложнена низким уровнем производительности труда в отрасли. Некоторые эксперты утверждают, что она в 8-10 раз ниже по сравнению с наиболее развитыми странами. Низкий уровень производительности труда обусловлен как недостаточными инвестиционно-технологическими факторами, так и неразвитостью иных сфер приложения труда сельских жителей.

Развитие сельского туризма и активное культурное строительство в сельской местности России сможет переломить ситуацию.

Ключевые слова: культурное строительство, сельская местность, культурное наследие, дома культуры, историческая память.

ного хозяйства; в-четвертых, меньшие возможности для образовательного и культурного развития.

Полностью убрать эти несоответствия не удалось даже в советский период, когда была запущена компания «по смычке города и деревне».

Сегодня эта ситуация разрешается посредством двух взаимодополняющихся, но не увязанных в единое целое процессов. Во-первых, современное культурное строительство новых домов культуры в рамках федерального проекта «Культурная среда» национального проекта «Культура», планируется к концу 2024 года построить, реконструировать или капитально отремонтировать 526 сельских культурно-досуговых объектов. Во-вторых, осуществление культурного строительства в рамках наполнения сельского туризма.

\footnotetext{
1 Работа выполнена при поддержке государственной фондовой комиссии по учебе за границей, при поддержке департамента образования провинции Хэйлунцзян (проект 135209521).

2 The work was carried out with the support of the state Foundation Commission for study abroad, with the support of the Department of education of Heilongjiang province (project 135209521).
} 
В частности, Распоряжение от 7 марта 2019 года №366-р утверждено распределение 282,9 млн. рублей на строительство домов культуры в 11 субъектах Федерации. 16 новых домов культуры будут построены в республиках Адыгея, Алтай, Кабардино-Балкарской, Карачаево-Черкесской, Чувашской республиках, Хабаровском крае, Архангельской, Астраханской, Воронежской, Курганской, Новгородской областях. [9]

Современное культурное строительство как наполнение объектов сельского туризма.

\section{ФунАамент культурного строительства}

Россия обладает уникальными природно-климатическими и культурно-историческими особенностями, позволяющими развивать практически все популярные виды туризма, одним из которых является сельский туризм. Надо отметить, что развитию сельского туризма в России способствует ухудшение и экологической, и психологической обстановки в крупных городах, городские жители стремятся отдыхать на экологически благоприятных территориях. Наблюдается возрождение интереса к элементам традиционной народной культуры: образцам народной архитектуры, кухни, ремеслам, фольклору, посещению российской глубинки как элемент ностальгии по крестьянской соборности, стремление к расширению сферы общения.

В предпринимательской среде выросла конкуренция в традиционных сферах инвестиции на селе. Идет поиск новых сфер и объектов инвестирования в том числе и в культурное строительство.

Следует отметить, что базой для налаживания системы сельского туризма является формирования культурных объектов и/или культурное строительство в сельской местности. В результате регулярное посещение восстановленных или реконструированных, либо построенных заново культурных объектов, сможет решить и ряд социально-экономических задач. Во-первых, обустройство сельских территорий. Во-вторых, создание новых рабочих мест, как для женщин, так и для сельской молодежи. В-третьих, комплексное использование природных и культурных потенциалов сельских территорий. В-четвертых, начнёт способствовать повышению привлекательности проживания в сельской местности.

В сельской местности сосредоточены объекты историко-культурного наследия народов Российской Федерации. Сельское население является хранителем традиционной культуры страны.

Село как социально-территориальная подсистема общества выполняет ряд важнейших общенациональных функций: прежде всего, демографическую, социального контроля над территорией, рекреационную и агрорекреационную, социально-культурную, природоохранную, производственную, трудоресурсную, жилищную и пространственно-коммуникационную.

В рамках демографической функции осуществляется восполнения демографического потенциала страны, здорового поколения, растущего в экологически чистых местах сельской местности.

Социальный контроль над территорией выражается в организации содействия органам местного самоуправления, а также органам государственной власти в обеспечении общественного порядка и безопасности на малолюдных территориях и в поселениях.

Рекреационная и агрорекреационная функция обеспечена возможностью разместить в сельской местности учреждений отдыха, оздоровления и туризма, дач и садово-огородных участков горожан, другие формы отдыха на природе, предоставление в пользование рекреационным учреждениям и отдельным гражданам в период отдыха объектов сельской социальной и инженерной инфраструктуры.

Социально-культурная функция обеспечивает как сохранение и развитие традиционной культуры народов Российской Федерации, так и воспроизводство историко-культурных ценностей,

Природоохранная функция способствует обеспечению экологического равновесия как на территории района или региона, в котором располагается сельское поселение, так и всей территории страны, что создаёт предпосылки для не только восстановления и сохранения потенциала живой природы, но и его улучшения.

В рамках производственной функции происходит удовлетворение потребностей общества, прежде всего, в продовольствии, кроме этого сельская местность способна поставлять сырье для промышленности, а также заготавливать и поставлять продукцию охотничье-промыслового, рыбного лесного хозяйства и иной несельскохозяйственной продукции.

Трудоресурсная функция включает в себя обеспечение рабочей силой существующие рабочие места, обеспечивая тем самым местный миграционный поток между сельскими поселениями и городом, в котором они и сосредоточены. Сельские жители, в большинстве своём, занимают те ниши по занятию рабочих мест, которые не востребованы горожанами, тем самым трудоспособное сельское население, проживающее в пригородах, активно используется на городских предприятиях, оно же привлекается для работы на размещаемых в сельской местности городскими хозяйствующими субъектами предприятиях (филиалах); 
Жилищная функция реализуется посредством размещения в экологически чистых сельских территориях жилых домов горожан, имеющих доходное занятие в городе, предоставление им в пользование объектов сельской социальной и инженерной инфраструктуры;

Пространственно-коммуникационная функция сельской местности может быть реализована посредством размещения и обслуживания дорог, линий электропередачи, связи, водопроводов и других инженерных коммуникаций;

Выполнение селом указанных функций - важнейшее условие успешного социально-экономического развития страны. Основой его развития может стать культурное строительство в сельской местности.

\section{Объекты культурного наследия}

В Ярославской области есть целые деревни, в которых все желающие могут получить мастер-класс по различным народным промыслам. В Псковской области большой популярностью пользуется деревня, где есть огромная баня вместимостью 30 человек. Иностранные туристические группы заезжают сюда по дороге из Питера в Москву. По своей популярности этот туристический объект может конкурировать с национальными музеями.

Жители Углича активно создают различные частные музеи: кукол, водки, чайников - список предметов показа весьма разнообразен и количество таких музеев в городе уже более 30. Наверняка, подобную возможность имеет каждое село. Главное - позиционировать своё дело как туристический объект и проводить активное продвижение, привлекая потенциальных партнеров и клиентов. Доход будет зависеть от усилий и фантазии, ведь туризм - это продажа новых впечатлений и положительных эмоций.

Концепция устойчивого развития сельских территорий, принятая на федеральном уровне, стимулировала разработку и принятие аналогичной концепции регионального уровня. Концепция устойчивого развития сельских территорий Вологодской области на период до 2020 г. принята 31.01.2011 г. В развитие этой концепции в регионе разработана программа развития агропромышленного комплекса и потребительского рынка Вологодской области на 2013-2020 гг. [8]

В июне 2012 г. в крае принята целевая программа «Устойчивое развитие сельских территорий Хабаровского края на 2013-2020 годы», ориентированная на направления концепции ФЦП «Устойчивое развитие сельских территорий на 2014-2017 годы и на период до 2020 года». В качестве регионального компонента усилены мероприятия по развитию сферы социально-бытового обслуживания в сельской местности, информационноконсультационному обслуживанию жителей села, подготовке кадров [7].

Туризм в Калужской области - это важная часть индустрии развлечений и активного отдыха. При этом серьезным помощником в развитии туризма стала провинция. Для желающих отдохнуть на природе в самых живописных районах Калужской области работает множество гостевых домов.

Например, в Московской области на границе с Калужской областью разместился новый парк «Берендеево царство», на базе местного поселка начала развиваться сказочная инфраструктура, которая активно строиться и сейчас. Уже введены в действие и работают на бесплатной основе Музей Сказок под открытым небом и Дворец царя Берендея. В ближайшее время достроят «Фермерскую слободу». Объект стилизован в русском стиле средневекового зодчества со своими башнями, торными рядами, крепостной стеной и удобными столами для проведения застольного праздника.

Скоро примет в свои ряды Парк для молодоженов, в котором можно провести старинный обряд венчания, интерактив для влюбленных и окунуться в тот самобытный мир, которым напоен каждый уголок этого замечательного места.

Уникальным заведением, выросшим на базе местного поселения в глубине Ярославской области, является историко-культурный объект «Русский парк», в котором удалось сохранить наследие русского народа за период XIX-XX столетия. Открытие состоялось в 2014 году и с этого момента не прекращается активный поток любителей русской старины, так как здесь представлены образцы культурного опыта, которые будут интересны взрослым и детям. В центре в Переславле-Залесском собрано более 1000 объектов, отражающих русскую культуру [5]. Они собраны в уличных экспозициях, музеях, на интерактивных площадках.

\section{Перспективы развития культурного строительства в сельской местности}

Развитие сельской местности нашей страны еще раз доказывает необходимость изучения свойств территории и их учета при принятии управленческих решений. Нельзя управлять сельской местностью из какого-либо центра (страны, республики, области, района) без учета территориальных различий:то, что хорошо на юге - вредно на севере, что необходимо в пригороде - бесполезно в глубинке [4], а также нельзя управлять каким-либо одним компонентом сельской местности, будь то земельные угодья, население, техническая оснащенность, без учета сложных взаимосвязей между ее компонентами. В этой связи, культурное строительство в полной мере 
может стать тем локомотивом, тем связующим звеном, которое потянет за собой и объединит все элементы сельских поселений.

Из этого вытекают три основные практические задачи культурного строительства в сельской местности. Вопервых, необходимо развивать и совершенствовать методы типологии и районирования сельской местности для различных целей и увязывать их в единый туристскорекреационный комплекс всего региона, кооперировав местное культурное строительство в единую перспективную программу развития региона и формирования целевого маршрута, в конкретную сельскую местность. Во-вторых, на более высокий уровень следует поставить налаживание взаимосвязей между соседними сельскими поселениями и формирование на этой базе целевого кластера, представляющего из себя целостное образование, способное создать предпосылки для системного развития всех его элементов. И в-третьих, необходимо как новые так и уже известные знания о сельской местности и выстроенных культурных объектах сделать частью общественного сознания с тем, чтобы сохранялась и восстанавливалась утраченная самобытность конкретного места, способные учитывать местные различия и находить то единое, что объединяет не только каждого местного жителя, но и любого посетителя. Поэтому участие населения в выработке и принятии решений, касающихся жизни своего района, развитие самоуправления и в целом демократизация общественной жизни важнейшие предпосылки успешного развития сельской местности нашей страны. [3]

\section{Зак^ючение}

Проводимые в агропромышленном комплексе России с 90-х годов социально-экономические реформы, резкое сокращение государственного финансирования АПК, медленное становление органов местного самоуправления привели к изменениям в социальной структуре сельского общества и оказали в целом негативное влияние на социальное развитие села, уровень и качество жизни большинства сельского населения. Качество и благополучие жизни крестьян, их социальные условия жизни резко отличаются от качества жизни людей в городских условиях.

При этом со стороны правительственных кругов уже делаются определенные шаги, направленные на создание объектов культуры в сельской местности, о чем свидетельствует финансирование федерального проекта «Культурная среда» национального проекта «Культура» рассчитанного до 2024 года. Отрадно отметить, что и со стороны бизнес сообщества шаги в аналогичном, но окупаемом варианте делаются и создаются культурные объекты, наполненные местным колоритом и вовлеченные в единую туристскую инфраструктуру конкретного региона.

Таким образом, культурное строительство в сельской местности на территории различных регионов страны ведется с существенно большей активностью, чем это было скажем в предыдущее десятилетие.

ЛИТЕРАТУРА

1. Постановление Правительства области от 31 января 2011 года №57 «0 Концепции устойчивого развития сельских территорий Вологодской области на период до 2020 года».// Информационно-справочная система КонсультантПлюс

2. Устойчивое развитие сельских территорий Хабаровского края на 2013-2020 годы. // Информационно-справочная система КонсультантПлюс

3. Андреева Н.П. Методические рекомендации по созданию в субъектах Российской Федерации объектов казачьего агротуризма с использованием отечественного и зарубежного опыта, М., Росинформагротех, 2014. - 246 с.

4. Бурмистрова А.А., Родионова Н.К,, Кондрашова И.С. Социально-экономические проблемы развития сельских территорий и пути их решения // Социально-экономические явления и процессы. - 2014. - № 4., С. 12 - 16.

5. Материалы сайта ttps://tonkosti.ru/Русский_парк_в_Переславле-Залесском

6. Состояние социально-трудовой сферы села и предложения по ее регулированию. Ежегодный доклад по результатам мониторинга. М.: Минсельхоз России, ГНУ ВНИИЭСХ, ФГНУ «РосинформагротеХ», 2013. - 114 с.

7. Постановление Правительства Хабаровского края от 07.07.2014 № 210-пр «0 мерах по реализации на территории Хабаровского края мероприятий федеральной целевой программы «Устойчивое развитие сельских территорий на 2014 - 2017 годы и на период до 2020 года». // Информационно-справочная система КонсультантПлюс

8. Концепция устойчивого развития сельских территорий Вологодской области на период до 2020. // Информационно-справочная система КонсультантПлюс

9. Распоряжение от 7 марта 2019 года №366-р. // Информационно-справочная система КонсультантПлюс

(c) Чжан Хунли (zhanghongli8335@126.com),Хэ Цян (heqiang1969@163.com).

Журнал «Современная наука: актуальные проблемы теории и практики» 